\title{
A Case Study on the Effect of Spirituality on Reducing Stress and Grief Caused by COVID-19
}

\author{
Reza Pourhosein ${ }^{1 *}$, Delara Madahzad ${ }^{2}$
}

${ }^{1}$ Department of Psychology, Faculty of Psychology and Education, University of Tehran, Tehran, Iran.

${ }^{2}$ Department of Psychology, Kish International Campus, University of Tehran, Kish, Iran.

*Corresponding Author: Department of Psychology, Faculty of Psychology and Education, University of Tehran, Iran. Email: prhosein@ut.ac.ir

Received Date: February 11 2021; Accepted Date: March 01, 2021; Published Date; March $08,2021$.

Citation: Reza Pourhosein, Delara Madahzad, A Case Study on the Effect of Spirituality on Reducing Stress and Grief Caused by COVID-19; J. Psychology and Mental Health Care. 6(1). Doi: 10.31579/2637-8892/116

Copyright: (C) 2021 Reza Pourhosein, This is an open-access article distributed under the terms of the Creative Commons Attribution License, which permits unrestricted use, distribution, and reproduction in any medium provided the original author and source are credited.

\section{Abstract}

Introduction: At the beginning of 2020, the Corona Virus created a major pandemic in the world that was associated with death in all countries. In addition to the many crises caused by this pandemic, a variety of mental disorders also emerged. One of the most common disorders in the acute phase of the disease was Stress and Depression in patients as well as the general population. During this time, many protocols have been proposed for managing stress and depression. In this study, the effect of Spirituality and Religious Behavior on reducing depression caused by grief and stress has been studied.

Presentation Case: Our case is a 45-year-old Iranian Muslim woman who witnessed the death of her husband at the beginning of the Corona pandemic, and she herself suffered from Covid 19. She has been quarantined and under treatment for three months. During this time, she was alone and could not even attend his wife's funeral and mourning. Due to quarantine, others did not contact him and only contacted him by phone. This person is a believer, has high spirituality and performs religious behaviors carefully, and believes that deep belief in God, spirituality, and performing religious behaviors can make suffering easier.

Conclusion: Through an in-depth and semi-structured interview with a phenomenological approach, it was found that she was able to overcome the stress caused by the Corona pandemic and Covid 19 and also the depression caused by mourning her husband by relying on deep religious beliefs. And keep yourself consistent in life. It was also concluded that if there were no religious beliefs and spirituality in this person, he could not overcome the stress of illness and grief of her husband divine worldview can increase spirituality and the power of compromise in the face of suffering.

Keywords: covid 19; Islam; spirituality; mourning; stress

\section{Introduction}

The Covid virus, which has plagued the world since the beginning of 2020, has caused a great deal of stress in addition to death and physical problems[1]. The feeling of acute and chronic anxiety caused the individual and social life of the people of the world to be disrupted and other psychological disorders to follow. Stress lowers a person's immune system [2]. Low immunity and high stress prepare a person for a disease. In this case, a vicious cycle is formed in which each component affects the reinforcement of the other component [3]. One of the consequences of this disorder is a decrease in life satisfaction and also a decrease in life expectancy [4]. For this reason, paying attention to death has become one of the examples of reducing hope and vitality in people's lives [5].

People naturally tend to manage and reduce stress when they constantly perceive stress and anxiety [6]. In classical psychological literature, many cognitive, behavioral and emotional strategies have been proposed. In addition to these strategies, attention to spirituality has a special position
[7]. In general, human beings find themselves in a situation where they see themselves closer to death than before, turning to spirituality and God [8]. As they approach spirituality, they experience a sense of calm [9].

The mechanism of this effect is that when the stressor enters the human as a stimulus, this stimulus is processed and perceived by the human cognitive organization [10]. In other words, perceived stress is influenced by organizational as well as human beliefs. Research has shown that spiritual people show greater resilience and resilience to stress as well as crises [11]. In this equation, spirituality is the mediating variable between stressor and stress perception [12].

Explaining the meaning of life as spirituality is common to all attitudes and schools; but in divine anthropology, spirituality is raised only in relation to Allah as the creator of the universe. Accordingly, in Islamic spirituality, all paths lead to Allah [13]. Man in stressful situations pays attention to the Creator of the world and asks him for help [14]. This man believes that when he asks God, he receives more peace [15]. In the culture of the Iranian people, this solution is one of the effective solutions 
to deal with suffering and crisis phenomena in addition to observing health protocols [16].

The aim of this study was to investigate the effect of spirituality and religious behavior in reducing stress and coping with grief.

\section{Case Report}

The case study is an Iranian woman, a 45-year-old Shiite Muslim, married with two children. This person has a religious attitude and performs religious behaviors such as hijab, prayer, fasting and other religious behaviors well. She did not take any psychotropic drugs. Her level of freshness has been high. She has no history of neurotic states and has observed social interactions and participations well. She has had good satisfaction in his life. Her husband died of Covid 19 disease in early 2020. She herself has coronary heart disease and is quarantined at home under the supervision of a doctor. She also mourned her husband during her days in quarantine.

She was unable to attend the funeral due to coronary heart disease, and none of her survivors, relatives and friends were able to meet or sympathize with her. She has both mourned her husband's death and suffered from coronary heart disease. She has also experienced some stress due to her illness and the condition of her children.

\section{Discussion}

In a study conducted by the researcher with different people on stress management, it was found that the Iranian population uses spirituality, prayer, prayer and pilgrimage to reduce the stress caused by Covid 19 to a great extent. Acquiring spirituality through prayer and spiritual connection to God Almighty is one of their beliefs and organization.

After interviewing the case, his statements were coded and content analyzed. His statement was classified into several main concepts.

1. Looking at life: "I think $100 \%$ about death and I am not afraid of it. But I also love life very much". "I have very few attachments to the world today. I think more about self-sacrifice", "I think my husband's grief and illness have been a test for me. So I have to wait", "I think about selfsacrifice in my life."

2. Resilience caused by spirituality: "Spiritual resilience that I could not bear mourning and illness without appealing to God and the Imams", "I am aware that I can endure these sufferings", "when I feel homesick and depressed, with I am calmed by dhikr, by reading the book and reciting the Qur'an, I endure the grief of being away from my husband". "The Qur'an is my nostalgia "."I had a good life. I was a little shaken by the death of my husband, but I endured it and came back to life."

3. How God feels in life: "I always feel that God cares for me", "When I call on Allah, I quickly calm down. He hears me and answers me".

In his view, belief in the divine worldview and religious behavior such as prayer, supplication and remembrance has been able to give him a positive outlook on life. Despite the death of her husband and suffering from coronary heart disease, she has been able to increase her tolerance by referring to Islamic spirituality and practicing religion. she believes that God will never forget him, and this belief has increased her resilience in the face of adversity and suffering. Her compromised behavior in the face of the stress of her husband's death and illness was due to her belief in God. This belief did not appear only during her illness, but she was a believer throughout her life and observed religious behavior in accordance with Islam. For this reason, her positive view of life stems from religion's view of life. For him, life is full of pleasures and sufferings. She believes that pleasures should not make us arrogant and careless; Suffering should not cause us too much anxiety. Suffering can be overcome and managed with patience.

\section{Limitations}

The interview with the case in question was after the illness had healed. It is better to do this study in a larger population.

\section{Conclusion}

Spirituality, especially Islamic spirituality, and performing religious behavior based on the divine worldview can effectively reduce the stress of an acute illness such as Covid 19 [17]. In fact, spirituality and religious behavior are important factors in managing stress $[18,19]$. The main reason for this effect is the organization of behaviors by religious beliefs as well as the performance of religious duties in the context of life. The spiritual man looks at the flow of life in a positive way and considers the text of life to be full of suffering and pleasure [20]. The case in question has been dominated by two painful phenomena of mourning the wife and at the same time, Covid 19 disease and enduring loneliness for 3 months. She believes that she could not recover in this suffering without prayer and supplication. She is now motivated to continue her life, despite feeling the consequences of Corvid's illness and mourning her husband.

\section{Acknowledgment}

The authors thank the woman who participated in this study and interview.

\section{Conflict of Interest}

The authors declare that there is no conflict of interests regarding the publication of this paper

\section{References}

1. Sahebi A, Nejati B, Moayedi S, Yousefi K, Torres M, et al. (2021). The prevalence of anxiety and depression among healthcare workers during the COVID-19 pandemic: An umbrella review of meta-analyses. Progress in NeuroPsychopharmacology and Biological Psychiatry. 110247.

2. Goodwin R, Wiwattanapantuwong J, Tuicomepee A, Suttiwan P, Watakakosol R, et al. (2021) Anxiety, perceived control and pandemic behaviour in Thailand during COVID-19: Results from a national survey. Journal of Psychiatric Research.

3. Arribathi AH, Suwarto, Miftakhu Rosyad A, Budiarto M, Supriyanti D, et al. (2021). An Analysis of Student Learning Anxiety during the COVID-19 Pandemic: A Study in Higher Education. The Journal of Continuing Higher Education. 1-4.

4. Yildirim H, Işik K, Aylaz R. (2021). The effect of anxiety levels of elderly people in quarantine on depression during covid-19 pandemic. Social Work in Public Health. 1-1.

5. Mukona DM, Zvinavashe M. (2020). Self-management of diabetes mellitus during the Covid-19 pandemic: Recommendations for a resource limited setting. Diabetes \& Metabolic Syndrome: Clinical Research \& Reviews.

6. Anderson G. (2020). Psychological Stress and Covid-19: Interactions with Gut Microbiome and Circadian Rhythm in Driving Symptom Severity. Preprint. London: CRC Scotland \& London.

7. Rettke H, Naef R, Rufer M, Peng-Keller S. (2021). Spirituality and health care. The perspective of patients with chronic pain. Schmerz (Berlin, Germany).

8. Ransome Y. (2020). Religion, spirituality, and health: new considerations for epidemiology. American journal of epidemiology. 189(8):755-758.

9. Maragh-Bass AC, Sloan DH, Alghanim F, Knowlton AR. (2020). A mixed-methods exploration of faith, spirituality, and health program interest among older African Americans with HIV. Quality of Life Research. 1-3. 
10. Villas Boas A. (2020). Spirituality and Health in Pandemic Times: Lessons from the Ancient Wisdom. Religions. 11(11):583.

11. Rettke H, Naef R, Rufer M, Peng-Keller S. (2021). Spirituality and health care. The perspective of patients with chronic pain. Schmerz (Berlin, Germany).

12. Scott Barss K. (2020). Spiritual care in holistic nursing education: a spirituality and health elective rooted in TRUST and contemplative education. Journal of Holistic Nursing. 38(1):122-30.

13. Ghanbari R, Mohammadimehr M. (2020). Investigating the Relationship between Islamic Spirituality and Spiritual Health with Professional Ethics among Internal Residents of Universities of Medical Sciences in Tehran. Iranian Journal of Medical Education. 20:12-21.

14. Ahmed MA, Hashim S, Yaacob NR. (2020). Islamic Spirituality, Resilience and Achievement Motivation of Yemeni .Refugee Students: A Proposed Conceptual Framework. International Journal of Learning, Teaching and Educational Research. 19(4).

15. Harun ZA. Impact of Islamic Spirituality (IS) and Islamic Social Responsibility (ISR) on Employee Engagement (EE) in Small and Medium Enterprises (SMEs) of Malaysia.

16. Muawanah U. (2020). Islamic Spirituality Governance: Model Praktik Corporatte Governance BPR Syariah. E-Repository Dosen Universitas Gajayana Malang.

17. Adawiyah WR, Pramuka BA. (2017). Scaling the notion of Islamic spirituality in the workplace. Journal of Management Development.

18. Sani A, Ekowati VM. (2019). Spirituality at work and organizational commitment as moderating variables in relationship between Islamic spirituality and OCB IP and influence toward employee performance. Journal of Islamic Marketing.

19. Zandi G, Kamil NM, Sulaiman M, Ishak IC, Sahudin S. (2017). Islamic spirituality and continuance organizational commitment: the case Of Malaysian organizations. Journal of Islamic Management Studies. 1(1):54-71.

20. Mulyaningtyas A, Winedar M, Sayidah N. (2019). Exploration of the Spirituality Values in Accountability of Islamic Organizations. Journal of Economics, Management and Trade. 23(5):1-0. 